\title{
A Comparative Evaluation of Heavy Metals in the Different Breads in Iran: A Case Study of Rasht City
}

\author{
Dariush Naghipour ${ }^{1}$; Abdoliman Amouei ${ }^{2, *}$; Shahrokh Nazmara ${ }^{3}$ \\ ${ }_{1}^{1}$ Department of Environmental Health Engineering, Faculty of Health, Guilan University of Medical Sciences, Rasht, IR Iran \\ 2 Department of Environmental Health Engineering, Babol University of Medical Sciences, Babol, IR Iran \\ 3 Department of Environmental Health Engineering, Tehran University of Medical Sciences, Tehran, IR Iran \\ ${ }^{*}$ Corresponding author: Abdoliman Amouei, Department of Environmental Health Engineering, Babol University of Medical Sciences, Babol, IR Iran. Tel: +98-1112234366, Fax: +98- \\ 1112234367, E-mail: iamouei1966@gmail.com
}

Received: February 11, 2014; Revised: June 17, 2014; Accepted: June 20, 2014

\begin{abstract}
Background: Bread is an important food product that furnishes as much as $50 \%$ to $90 \%$ of total calorie and protein intakes.
Objectives: This research was aimed at investigating content of heavy metals in the different breads in Rasht metropolis of northern Iran. Materials and Methods: A total of 40 different bread types such as Barbari, Sangak, Lavash, and Baguette produced in 124 bakery shops in Rasht City were analyzed for some heavy metals (As, $\mathrm{Cd}, \mathrm{Pb}, \mathrm{Cr}$, Ni, and $\mathrm{Co}$ ) by Inductive Coupled Plasma (ICP) instrument (ICP-QES).

Results: The mean content of the As, Cd, and $\mathrm{Pb}$ in different breads were respectively as follows: Barbari, 0, 0.73, and 0.07; Sangak, 0, 0.13, and 0.64; Lavash, 0, 0.2, and 0.3; and Baguette, 0, 0.09, and $0.9 \mathrm{mg} / \mathrm{kg}$ of dry weight. The mean concentration of $\mathrm{Cr}$, $\mathrm{Ni}$, and Co levels in the selected breads was respectively as follows: $1.3,1.2$, and $0.6 \mathrm{mg} / \mathrm{kg}$ of Barbari; $0.8,0.6$, and $0.19 \mathrm{mg} / \mathrm{kg}$ of Sangak; 0.7, 0.4, and $0.14 \mathrm{mg} / \mathrm{kg}$ of Lavash; and 0.9, 0.7, and $0.07 \mathrm{mg} / \mathrm{kg}$ of Baguette. The mean daily intake of $\mathrm{As}, \mathrm{Cd}, \mathrm{Pb}, \mathrm{Cr}, \mathrm{Ni}$, and $\mathrm{Cr}$ with the consumed breads were $0,0.5$, $4.2,6.4,7.4$, and $1.6 \mu \mathrm{g} / \mathrm{kg}$, respectively. The total daily intake of the studied heavy metals was determined $17.5 \mu \mathrm{g} / \mathrm{kg}$. The high levels $\mathrm{Cr}(8.4$ $\mu \mathrm{g} / \mathrm{kg})$ in Barbari, $\mathrm{Pb}(5.8 \mu \mathrm{g} / \mathrm{kg})$ in Baguette, and Cd $(0.8 \mu \mathrm{g} / \mathrm{kg})$ in Sangak breads were determined.

Conclusions: The high contents of daily intake of $\mathrm{Cr}, \mathrm{Pb}, \mathrm{Cd}$, and $\mathrm{Hg}$ by the breads cause undesirable health effects on people. Prevention of heavy metals in to the durums and breads during wheat, rice, and other agricultural productions in cultivation, harvest, and grinding stages, storage of flour, and baking breads is necessary.
\end{abstract}

Keywords:Bread; Triticum; Metals; Acceptable Daily Intake

\section{Background}

Nutritional concerns about cereal-based diets are important issues worldwide, especially vitamin and mineral deficiency in susceptible individuals such as children younger than five years and women at reproductive age (1). Mineral compounds are essential to daily food needs (2). Bread is an important food products that furnishes as much as $50 \%$ to $90 \%$ of total calorie and protein intakes (3). Because of high consumption of wheat in a variety of food products, it is considered an important source of mineral compounds (1). Heavy metals are the most noxious materials, due to no biodegradability and their potential to cause inappropriate effects $(4,5)$. The presence of heavy metals in food is determined by some factors such as environmental parameters, mode of production, and processing $(6,7)$. The effect of environmental pollution on contamination of foods and on their safety for human consumption is a serious global issue $(8,9)$. Many reports have investigated the heavy metals contents in foodstuff(10-12). Some heavy metals such as lead (Pb), cadmium (Cd), and nickel ( $\mathrm{Ni}$ ) are extendedly used in various industrial centers (13). These elements are non-essential materials for nearly all living creatures. $\mathrm{Pb}, \mathrm{Cd}$, and other heavy metals can enter wheat flour and then bread $(10,13)$. It has been reported that all types of grain contain trace metals such as iron (Fe), manganese (Mn), magnesium $(\mathrm{Mg})$, copper $(\mathrm{Cu})$, and zinc $(\mathrm{Zn})$, which might be due to environmental condition such as weather during cultivation, rain, and levels of contamination $(5,14)$. Application of chemical fertilizer and using sewage sludge during the cultivation of cereals will substantially increase the levels of $\mathrm{Pb}, \mathrm{Zn}$, and $\mathrm{Cd}$ (9). Food processing equipment and containers have been long recognized as a source of trace metals such as $\mathrm{Fe}, \mathrm{Cu}, \mathrm{Pb}$, and chromium $(\mathrm{Cr})$ in the processed foods (14). Iranian breads like, Barbari, Lavash, Taftoon, and Sangak are mainly produced from wheat flours (10). The important subject in field of food sciences is daily intake of food materials $(1,2)$. The daily intake of bread in Iran is 420 gram per person (15). This quantity in the United States, the West Europe, Russia, and Turkey is $55,274,164$, and 400 gram per person. Mean daily intake of bread in the world is 330 to 410 gram per person (12).

\section{Objectives}

The aim of this study was to determine the contents of 
heavy metals including $\mathrm{Pb}, \mathrm{Cd}, \mathrm{Cr}, \mathrm{Ni}$, Co, arsenic (As) in selected samples of breads that were baked in bakeries (124 bakery stores) of Rasht City in 2013. In addition, the daily intake of these heavy metals was determined based on bread per capita consumption.

\section{Materials and Methods}

In this study, 40 samples of several types of bread were collected from bakeries in different areas of Rasht city, center of Guilan province, Iran. This research was performed by two duplicates with a replicates. There are different types of bakery in north provinces of Iran. These bakeries produce several types of bread such as Barbari, Lavash, Sangak, and Baguette. Forty pieces of these breads were randomly collected from 124 bakeries at different areas of Rasht City in 2013. Bread samples were prepared according to Khaniki et al. (10). First, the bread samples were left to air dry before sub-sample were taken from each group and then were ground with Titanium knives and stored in high-density polyethylene bottles with $100 \mathrm{~mL}$ capacity. These bottles were washed with $1 \%$ hydrochloric acid and raised with deionized water. One gram of the prepared samples were precisely weighed and transferred into the 50-mL Erlene Mayer and $3 \mathrm{~mL}$ of $65 \%$ nitric acid was added. Total samples were located overnight at room temperature and then were heated up $130^{\circ} \mathrm{C}$ for three hours using a hot plate. After cooling the samples, $2 \mathrm{~mL}$ of nitric acid, $0.7 \mathrm{~mL}$ of perchloric acid and $43 \mathrm{~mL}$ of distilled water were added to each sample.

Table 1. Flame Conditions and Other Characteristics of Instrument for the Measurement of the Heavy Metals ${ }^{\text {a }}$

\begin{tabular}{lcc}
\hline Element & Wave Length, nm & Detection Limit, ppb \\
\hline $\mathbf{A s}$ & 189 & 1.19 \\
$\mathbf{P b}$ & 283.3 & 2.1 \\
$\mathbf{C d}$ & 228.8 & 0.05 \\
$\mathbf{C r}$ & 267.7 & 0.1 \\
$\mathbf{C o}$ & 228.6 & 0.05 \\
$\mathbf{N i}$ & 231.6 & 0.3 \\
\hline a Instrument conditions, ICP-QES (Spectro arcos); pump rate, 30 rpm; & \\
ICP torch injector, 2.5 mm; RF power, 1400 w; plasma gas flow rate, 14.5/ \\
min; auxiliary gas flow rate, $0.9 /$ min; and nebulizer gas flow rate, $0.85 /$ \\
min.
\end{tabular}

Total samples were heated for three hours in temperature $230^{\circ} \mathrm{C}$ and dissolved in $5 \mathrm{~mL}$ of distilled water. Total samples were analyzed by Inductive Couple Plasma spectrometry (ICP-Qes-Spectro arcos, Germany) to determine the heavy metal content. Working condition of the used ICP instrument is presented in Table 1.

\subsection{The Daily Intake of Heavy Metals Through Bread Consumption}

The daily intake of heavy metals through bread consumption was determine with the following equation $(1,2)$ :

$$
\mathrm{DI}_{H . M}=\frac{C \times \mathrm{DI}_{\text {Bread }}}{B . W}
$$

$\mathrm{DI}_{\text {H.M }}=$ Daily Intake of Heavy Metal ( $\left.\mu \mathrm{g} / \mathrm{kgday}\right)$.

$\mathrm{C}=$ Heavy Metal Concentration in Bread ( $\mathrm{mg} / \mathrm{kg})$.

$\mathrm{DI}_{\text {Bread }}=$ Average Daily Intake of Bread (g/day).

BW = Body Weight (kg). In this study, body weight was determined as $65 \mathrm{~kg}$.

According to Food and Drug Organization of Iran, average daily intake of bread in Iran is 420 gram per person (15).

\section{Results}

\subsection{Heavy Metals Contents in the Different Breads}

The results of this study showed that the concentration of $\mathrm{Pb}, \mathrm{Cd}, \mathrm{Cr}, \mathrm{Ni}$, and $\mathrm{Co}$ in the Barbari bread samples ranged respectively from 0 to 1.3 , from 0.025 to 0.4 , from 0.7 to 2.8 , from 0.5 to 2.4 , from 0.2 to 1.8 , and from 0.016 to $0.1 \mathrm{mg} / \mathrm{kg}$. The $\mathrm{Pb}, \mathrm{Cd}, \mathrm{Cr}, \mathrm{Ni}$, and Co contents in Sangak bread ranged respectively from 0 to 2.7 , from 0 to 0.15 , from 0.86 to 2.3 , from 0.47 to 0.88 , from 0 to 0.8 , and from 0.01 to 0.15 . The concentration of the studied heavy metals, ie, $\mathrm{Pb}, \mathrm{Cd}, \mathrm{Cr}, \mathrm{Ni}$, and $\mathrm{Co}$ in Lavash ranged respectively from 0 to 1.4 , from 0 to 0.05 , from 0.34 to 1.76 , from 0.24 to 0.75 , from 0 to 1 , and from 0.02 to $0.16 \mathrm{mg} / \mathrm{kg}$. According to these results, $\mathrm{Pb}, \mathrm{Cd}, \mathrm{Cr}, \mathrm{Ni}$ and Co content of Baguette breads ranged respectively from 0 to 3.3 , from 0 to 0.3 , from 0.71 to 1.38 , from 0.35 to 1.58 , from 0 to 0.2 , and from 0.01 to $0.14 \mathrm{mg} / \mathrm{kg}$. In this study, the concentration of As was below detection limits in all of the samples (Table 2).

\begin{tabular}{|c|c|c|c|c|c|c|c|}
\hline Type of Bread & $\mathbf{P b}$ & Cd & $\mathrm{Cr}$ & $\mathbf{N i}$ & Co & As & Total \\
\hline Barbari & 4.7 & 0.4 & 8.4 & 7.8 & 3.9 & ND & 25.6 \\
\hline Sangak & 4.1 & 0.8 & 5.2 & 3.9 & 1.2 & ND & 15.6 \\
\hline Lavash & 2.1 & 0.1 & 4.5 & 2.6 & 0.9 & ND & 10.8 \\
\hline Baguette & 5.8 & 0.6 & 5.8 & 4.5 & 0.5 & ND & 17.6 \\
\hline Value $^{\mathrm{b}}$ & 4.2 & 0.5 & 6 & 4.7 & 1.6 & ND & 17.5 \\
\hline $\mathrm{DI}, \mu \mathrm{g} / \mathrm{kg}^{\mathrm{C}}$ & 3.6 & 1 & - & - & - & 2.5 & - \\
\hline PTWI $^{\mathrm{d}}$ & 25 & 7 & - & - & - & 15 & - \\
\hline
\end{tabular}

${ }^{a}$ Abbreviations: ND, non-detectable; DI, daily intake; PTWI, provisional tolerable weekly intake.

b Data are presented as mean.

c FAO/WHO daily intake.

$\mathrm{d}$ FAO/WHO provisional tolerable weekly intake. 

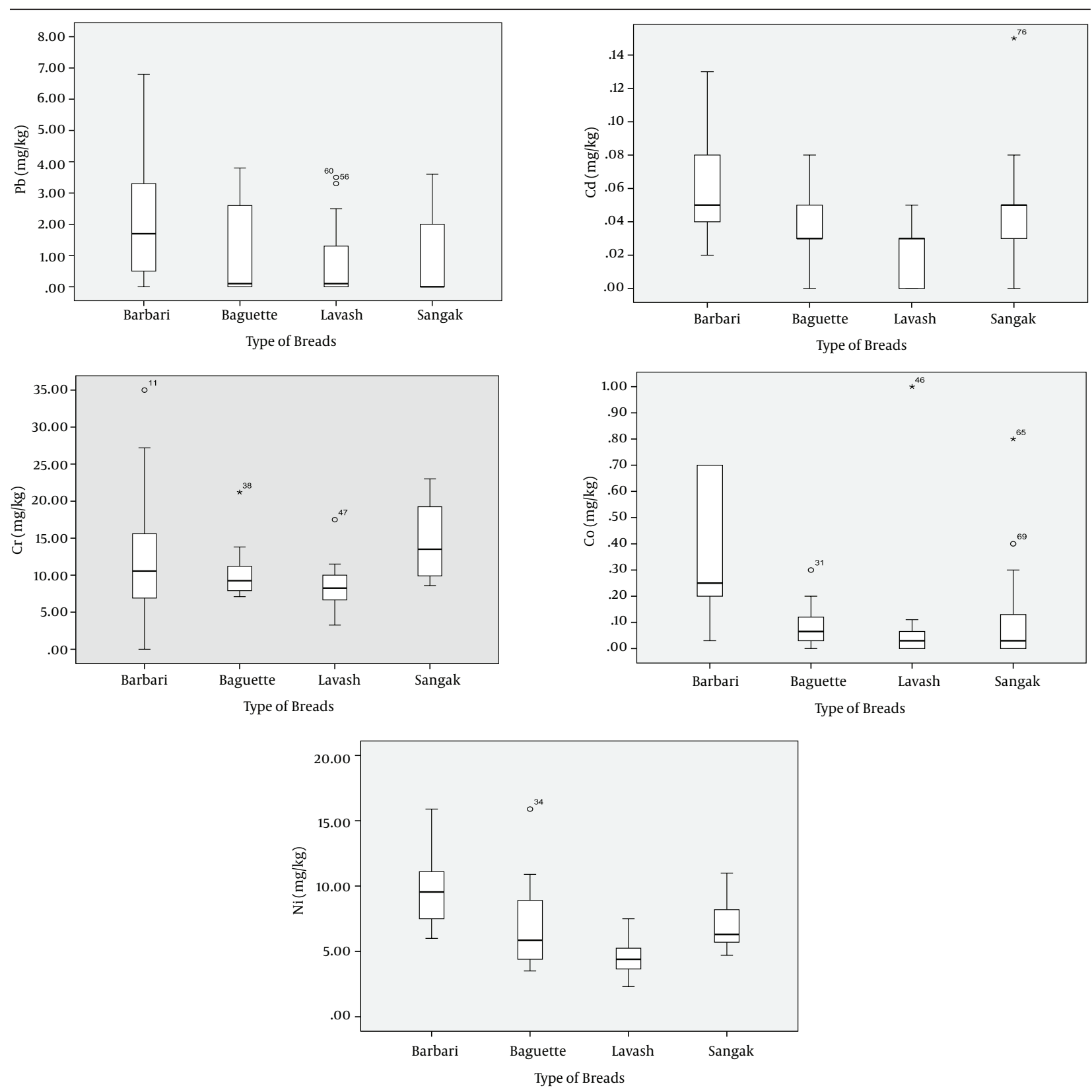

Figure 1. Mean Contents of Heavy Metals in the Investigated Breads

\subsection{The Daily Intake of Heavy Metals Through} Bread Consumption

In Table 2, daily intake of the studied heavy metals was presented. The daily intake of $\mathrm{Pb}, \mathrm{Cd}, \mathrm{Cr}, \mathrm{Ni}$, and $\mathrm{Co}$ ranged respectively from 2.1 to 5.8 , from 0.1 to 0.8 , from 4.5 to 8.4 , from 2.6 to 7.8 , and from 0.5 to $3.9 \mu \mathrm{g} / \mathrm{kg}$.

\section{Discussion}

We investigated the levels of heavy metals for the 40 samples of different breads collected from bakeries of Rasht city. In this research, the average values of $\mathrm{Cr}$ for the different breads were more than other heavy metals. The levels of $\mathrm{Cr}$ in the bread samples ranged from 0.34 to 2.7 $\mathrm{mg} / \mathrm{kg}$ and the mean contents of this element in Barbari, Sangak, Lavash, and Baguette were determined as 1.3, 0.8, 0.7 , and $0.9 \mathrm{mg} / \mathrm{kg}$, respectively. The levels of $\mathrm{Cr}$ had no significant difference between different breads. Cd concentrations ranged from 0 to $3.3 \mathrm{mg} / \mathrm{kg}$, with mean level of $0.13 \mathrm{mg} / \mathrm{kg}$ in Barbari, $0.07 \mathrm{mg} / \mathrm{kg}$ in Sangak, $0.02 \mathrm{mg} /$ $\mathrm{kg}$ in Lavash, and $0.09 \mathrm{mg} / \mathrm{kg}$ in Baguette. The mean levels of $\mathrm{Pb}$ in Barbari, Sangak, Lavash, and Baguette breads were $0.64,0.73,0.33$, and $0.9 \mathrm{mg} / \mathrm{kg}$, respectively. The levels of $\mathrm{Pb}$ in the bread samples showed a large varia- 
tion among the different breads; the highest content of $\mathrm{Pb}$ in Baguette bread was approximately three-times higher than the lowest level in Lavash bread. The average contents of Ni in Barbari, Sangak, Lavash, and Baguette breads were found to be $1.2,0.6,0.4$, and $0.7 \mathrm{mg} / \mathrm{kg}$ with no statistically significant differences among them. The levels of $\mathrm{Ni}$ in all breads ranged from 0.24 to $2.8 \mathrm{mg} / \mathrm{kg}$. The Co levels in the studied breads ranged from 0 to 1.8 $\mathrm{mg} / \mathrm{kg}$ and the mean contents of this metal were 0.6 , $0.19,0.14$, and $0.07 \mathrm{mg} / \mathrm{kg}$ respectively in Barbari, Sangak, Lavash, and Baguette breads. Barbari had the highest average levels of Co among other breads. In this study, As could not be detected in samples. The results revealed the order of heavy metals concentrations in bread samples were as follows: $\mathrm{Cr}>\mathrm{Ni}>\mathrm{Pb}>\mathrm{Co}>\mathrm{Cd}>$ As. Khaniki et al. studied heavy metals contents in the different breads. In this study, variation of $\mathrm{Pb}, \mathrm{Cd}$, and $\mathrm{Ni}$ have been found to range respectively from 0.27 to 0.52 , from 0.12 to 0.65 , and from 0.45 to $2.67 \mathrm{mg} / \mathrm{kg}$ (10). Jawad et al. showed that contents of $\mathrm{Pb}$ and $\mathrm{Cd}$ in the breads of Baghdad were respectively 0.33 and $0.07 \mathrm{mg} / \mathrm{kg}$ (6). Harmankaya et al. reported $\mathrm{Cr}$, Ni and $\mathrm{Zn}$ levels in the breads of Turkey to be $0.47,0.72$, and $20.9 \mathrm{mg} / \mathrm{kg}$, respectively (13). In another research, mean levels of $\mathrm{Cd}, \mathrm{Cr}$, and $\mathrm{Ni}$ in the flour of breads in Kalabar City (Nigeria) were determined as 0.002, 0.012, and $0.06 \mathrm{mg} / \mathrm{kg}$, respectively, while $\mathrm{Hg}$ and As were not detected in these breads (16). Magomia et al. found that $\mathrm{Pb}$ and $\mathrm{Cd}$ contents in the breads range from 0.34 to 3.13 and from 0.013 to $0.098 \mathrm{mg} / \mathrm{kg}$, respectively (17). Tumir et al. showed that the levels of $\mathrm{Pb}, \mathrm{Cd}, \mathrm{As}, \mathrm{Hg}$, and $\mathrm{Cr}$ range from 0.25 to 3.86 , from 0.05 to 0.28 , from 0.1 to 0.19 , from 0.02 to 0.12 , and from 0.11 to $64.4 \mathrm{mg} / \mathrm{kg}$, respectively, in dietary supplements on the Croatian market (18). In another research in Tenerif City of Spain, mean contents of $\mathrm{Pb}$ and $\mathrm{Cd}$ in the wheat of breads were determined as 0.037 and $0.027 \mathrm{mg} / \mathrm{kg}$, respectively (19).

Estimated daily intake of $\mathrm{Cd}, \mathrm{Pb}, \mathrm{Cr}, \mathrm{Ni}$, and $\mathrm{Co}$ according to consumption of different breads was performed using market basket. The daily intake of $\mathrm{Cd}$, based on Barbari, Sangak, Lavash, and Baguette breads consumption were $0.4,0.8,0.1$, and $0.6 \mu \mathrm{g} / \mathrm{kg}$, respectively, with the mean of $0.5 \mu \mathrm{g} / \mathrm{kg}$. Estimated daily intake of Cd through diet, calculated for a standard individual, was $15.66 \mu \mathrm{g}$ per day (2). The daily intake of $\mathrm{Pb}$ from the breads samples were $4.7,4.1,2.1$, and $5.8 \mu \mathrm{g} / \mathrm{kg}$, respectively, with the mean of $4.2 \mu \mathrm{g} / \mathrm{kg}$. Estimated $\mathrm{Pb}$ intake for a standard individual was $28.37 \mu \mathrm{g}$ per day and the largest proportion of this intake corresponds to cereals, with $4.94 \mu \mathrm{g} / \mathrm{kg}$, followed by fish and meat with respectively $4.71 \mu \mathrm{g} /$ day and $4.44 \mu \mathrm{g} /$ day (20). Llobet et al. determined the most daily intake contents of As, $\mathrm{Cd}, \mathrm{Hg}$, and $\mathrm{Pb}$ from foodstuff in Catalonia to be respectively 223.6, 15.7, 21.2, and $28.4 \mu \mathrm{g} /$ day (21). In this research, the mean daily estimated intake for $\mathrm{Cr}, \mathrm{Ni}$, and Co from different breads was respectively $6,4.7$, and $1.6 \mu \mathrm{g} / \mathrm{kg}$.

Different factors affect the heavy metals contamination in foodstuff and breads. One of the most important contaminations source of breads is environmental pollution, especially agricultural soils pollution with heavy metals (13). In these areas, heavy metals are transferred to roots of agricultural plants such as wheat, rice, and other cereals. Another way of heavy metals contamination is preparation and processing operations in the consumed breads. During the processing and preparation of breads, some additive materials such as contaminated water, salt, yeast, and baking soda can contaminate the breads with heavy metals (10). in addition, bread baking in the metal trays (10), contaminated bakery ovens due to lack of surveillance, and fuels contaminated with heavy metals (7) are other contamination parameters. Secondary pollution with heavy metals in the breads includes packaging and urban and bakery air pollution are other ways of bread contamination.

\section{Authors' Contributions}

The overall implementation of this study including design, experiments, data analysis, and manuscript preparation were the result of joint efforts by individuals who are listed as co-authors of this paper. All authors have made extensive contribution to the review and finalization of this manuscript.

\section{Funding/Support}

This work was financially supported by the Research and Technology Assistance of Guilan University of Medical Sciences, Rasht, Iran (grant no. 21077027).

\section{References}

1. Gorchev HG, Jelinek CF. A review of the dietary intakes of chemical contaminants. Bull World Health Organ. 1985;63(5):945-62.

2. European Food Safety Authority (EFSA). Statement on tolerable weekly intake for Cadmium. Eur Food Saf Auth. 2012;9(2):1975-80.

3. Jahed Khaniki GR. Determination of Zinc Contents in Iranian Flat Breads. Pakistan J Nutr. 2005;4(5):294-7.

4. Fraga CG. Relevance, essentiality and toxicity of trace elements in human health. Mol Aspects Med. 2005;26(4-5):235-44.

5. Demirozu B, Saldamli I. Metallic contamination problem in a pasta production plant. Turkish J Eng Sci. 2002;26(4):361-6.

6. Jawad I, Allafaji SH. The levels of Trace Metals Contaminants in Wheat Grains, Flours and Breads in Iraq. Aust J Basic Appl Sci. 2012;6(10):88-92.

7. Alomary A, Wedian F. The Influence of Baking Fuel Types on the Residues of Some Heavy Metals in Jordanian Bread. Jordan $j$ Chem. 2012;7(1):81-5.

8. Yanardag AB, Mermut A, Cano AF, Carmona Garces DM, Yanardag IH, editors. Heavy Metal Contents of Soils, Durum and Bread Wheats in Harran Plain, Southeast Turkey.; EGU General Assembly Conference Abstracts.; 2013; p. 7299.

9. Hassan N, Mahmood Q, Waseem A, Irshard M, Pervez A. Assessment of heavy metals in wheat plants irrigated with contaminated wastewater. Pol J Environ Stud. 2013;22(1):115-23.

10. Khaniki GRJ, Yunesian M, Mahvi AH, Nazmara S. Trace metal contaminants in Iranian flat breads. J Agric Soc Sci. 2005;1(4):301-3.

11. Doe ED, Awua AK, Gyamfi OK, Bentil NO. Levels of Selected Heavy Metals in Wheat Flour on the Ghanaian Market: A Determination by Atomic Absorption Spectrometry. Ame J Appl Chem. 2013;1(2):17-21.

12. Garcia-Rico L, Leyva-Perez J, Jara-Marini ME. Content and daily intake of copper, zinc, lead, cadmium, and mercury from dietary supplements in Mexico. Food Chem Toxicol. 2007;45(9):1599-605. 
13. Harmankaya M, Ozcan MM, Gezgin S. Variation of heavy metal and micro and macro element concentrations of bread and durum wheats and their relationship in grain of Turkish wheat cultivars. Environ Monit Assess. 2012;184(9):5511-21.

14. Onianwa PC, Adeyemo AO, Idowu OE, Ogabiela EE. Copper and zinc contents of Nigerian foods and estimates of the adult dietary intakes. Food Chem. 2001;72(1):89-95.

15. Iran Health Ministry . Drug \& Food Organization. 2007. Available from: http://www.behdasht.gov.ir/.

16. Christophe E, Iniama G, Osabor V, Etiuma R, Ochelebe M. A Comparative Evaluation of Heavy Metals in Commercial Wheat Flours Sold in Calabar-Nigeria. Pakistan J Nutr. 2009;8(5):585-7.

17. Magomia AM, Yebpella GG, Udiba UU, Amos H, Latayo MS. Potassium Bromate and heavy metals contents of selected bread samples produced in Zaria, Nigeria. Int j Sci Tech. 2013;2(2):232-7.

18. Tumir H, Bošnir J, Vedrina-Dragojević I, Dragun Z, Tomić S, Puntarić D, et al. Monitoring of metal and metalloid content in dietary supplements on the Croatian market. Food Control. 2010;21(6):885-9.

19. Tejera RL, Luis G, Gonzalez-Weller D, Caballero JM, Gutierrez AJ, Rubio C, et al. Metals in wheat flour; comparative study and safety control. Nutr Hosp. 2013;28(2):506-13.

20. European Food Safety Authority . Scientific opinion on lead in food. Eur Food Saf Aut J. 2010;8(4):1570-80.

21. Llobet JM, Falco G, Casas C, Teixido A, Domingo JL. Concentrations of arsenic, cadmium, mercury, and lead in common foods and estimated daily intake by children, adolescents, adults, and seniors of Catalonia, Spain. J Agric Food Chem. 2003;51(3):838-42. 